$\boldsymbol{S}$ THE POLITICS OF THE HEADSCARF IN THE UNITED STATES 



\section{THE POLITICS OF THE HEADSCARF IN THE UNITED STATES}

BOZENA C. WELBORNe, Aubrey L. WestFall, ÖZgE ÇELIK RUSSELL, AND SARAH A. TOBIN 


\section{Copyright (C) 2018 by Cornell University}

All rights reserved. Except for brief quotations in a review, this book, or parts thereof, must not be reproduced in any form without permission in writing from the publisher. For information, address Cornell University Press, Sage House, 512 East State Street, Ithaca, New York 14850.

First published 2018 by Cornell University Press

Printed in the United States of America

Library of Congress Cataloging-in-Publication Data

Names: Welborne, Bozena C., author. | Westfall, Aubrey L., author. | Russell, Özge Çelik, author. | Tobin, Sarah A., 1977- author.

Title: The politics of the headscarf in the United States / Bozena C. Welborne, Aubrey L. Westfall, Özge Çelik Russell, and Sarah A. Tobin.

Description: Ithaca : Cornell University Press, 2018. Includes bibliographical references and index.

Identifiers: LCCN 2017046634 (print) | LCCN 2017047979 (ebook) | ISBN 9781501715389 (epub/mobi) | ISBN 9781501715396 (pdf) | ISBN 9781501715365 | ISBN 9781501715365 (cloth ; alk. paper) | ISBN 9781501715372 (pbk. ; alk. paper)

Subjects: LCSH: Hijab (Islamic clothing)—Political aspectsUnited States. | Hijab (Islamic clothing)—Social aspectsUnited States. | Muslim women —Clothing-United States. | Muslim women-United States-Attitudes. | Clothing and dress-Religious aspects-Islam. | Islam-United States-Public opinion. | Public opinion-United States. Classification: LCC BP190.5.H44 (ebook) | LCC BP190.5. H44 W45 2018 (print) | DDC 297.5/76-dc23

LC record available at https:/ /ccn.loc.gov/2017046634

Cornell University Press strives to use environmentally responsible suppliers and materials to the fullest extent possible in the publishing of its books. Such materials include vegetable-based, low-VOC inks and acid-free papers that are recycled, totally chlorine-free, or partly composed of nonwood fibers. For further information, visit our website at cornellpress.cornell.edu. 